\title{
Development of Genetically Engineered Mice Lacking All Three Nitric Oxide Synthases
}

\author{
Masato Tsutsui ${ }^{1, *}$, Hiroaki Shimokawa ${ }^{2}$, Tsuyoshi Morishita ${ }^{3}$, Yasuhide Nakashima ${ }^{3}$, \\ and Nobuyuki Yanagihara ${ }^{1}$ \\ ${ }^{I}$ Department of Pharmacology, School of Medicine, University of Occupational and Environmental Health, \\ 1-1 Iseigaoka, Yahatanishi-ku, Kitakyushu 807-8555, Japan \\ ${ }^{2}$ Department of Cardiovascular Medicine, Tohoku University Graduate School of Medicine, \\ 1-1 Seiryo-machi, Aoba-ku, Sendai 980-8574, Japan \\ ${ }^{3}$ Second Department of Internal Medicine, School of Medicine, University of Occupational and Environmental Health, \\ 1-1 Iseigaoka, Yahatanishi-ku, Kitakyushu 807-8555, Japan
}

Received August 2, 2006

\begin{abstract}
Nitric oxide (NO) is produced in almost all tissues and organs, exerting multiple biological actions under both physiological and pathological conditions. NO is synthesized by three different isoforms of NO synthase (NOS): neuronal, inducible, and endothelial NOSs. Due to the substantial compensatory interactions among the NOS isoforms, the ultimate roles of endogenous NO in our body still remain to be fully elucidated. To address this point, we have successfully developed mice in which all three NOS genes are completely disrupted. NOS expression and activities were totally absent in the triply $\mathrm{n} / \mathrm{i} / \mathrm{eNOS}^{-/-}$mice before and after treatment with lipopolysaccharide. While the triply $\mathrm{n} / \mathrm{i} / \mathrm{eNOS}^{-/-}$mice were viable, their survival and fertility rates were markedly reduced as compared with wild-type mice. The phenotypes of those mice that we first noticed were polyuria, polydipsia, and renal unresponsiveness to vasopressin, characteristics consistent with nephrogenic diabetes insipidus. We subsequently observed that in those mice, arteriosclerosis is spontaneously developed with a clustering of cardiovascular risk factors. These results provide the first evidence that the systemic deletion of all three NOSs causes a variety of cardiovascular diseases in mice, demonstrating a critical role of the endogenous NOSs system in maintaining cardiovascular homeostasis.
\end{abstract}

Keywords: nitric oxide synthase, knockout mouse, cardiovascular disease, nephrogenic diabetes insipidus, metabolic syndrome

\section{Introduction}

Nitric oxide (NO), an important intracellular messenger molecule, plays important roles in maintaining homeostasis $(1-6)$. NO is formed from its precursor L-arginine by a family of NO synthases (NOSs) with stoichiometric production of L-citrulline. $\mathrm{NO}$ is a gaseous free radical that can freely pass through plasma membranes and then elicits multiple actions without

*Corresponding author. mt2498@med.uoeh-u.ac.jp Published online in J-STAGE: October 7, 2006 doi: 10.1254/jphs.CPJ06015X

Invited article receptor coupling either directly or via the soluble guanylate cyclase/cGMP-mediated pathway. Three distinct NOS isoforms exist that are encoded by three distinct genes: neuronal (nNOS, NOS1), inducible (iNOS, NOS2), and endothelial NOS (eNOS, NOS3) $(1-6)$. nNOS and eNOS are constitutively expressed mainly in the nervous system and the vascular endothelium, respectively, synthesizing a small amount of NO in a calcium-dependent manner both under basal conditions and upon stimulation. In contrast, iNOS is induced when stimulated by microbial endotoxins or certain proinflammatory cytokines, producing a larger amount of NO in a calcium-independent manner $(1-6)$.

Genetically engineered animals are a powerful experimental tool for studying the function of target genes 
in vivo. Animals bearing targeted deletions of singly and doubly NOS isoforms have thus been developed $(7-17)$. nNOS-deficient $\left(\mathrm{nNOS}^{-/-}\right)$mice exhibit hypertrophy of the pyloric sphincter (9), increased aggressive behavior (13), and protection from cerebral ischemia (18). eNOS $^{-/}$mice are hypertensive (10), susceptible to cerebral ischemia (19), and show accelerated vascular lesion formation (20). The principle phenotype of $\mathrm{iNOS}^{-/-}$mice is an increased susceptibility to infection with pathogens and resistance to the hypotensive response when exposed to bacterial lipopolysaccharide (LPS) (17). In doubly $\mathrm{n} / \mathrm{eNOS}^{-/-}$mice, but not in singly $\mathrm{nNOS}^{-/-}$or $\mathrm{eNOS}^{-/-}$mice, hippocampal long-term potentiation is blunted (15). Thus, the roles of individual NOS have been extensively studied. However, due to the substantial compensatory interactions among the NOS isoforms (15), the ultimate roles of NO derived from the whole NOS system remain to be fully elucidated.

We have recently succeeded in developing mice in which all three NOS isoforms are totally deficient (triply $\mathrm{n} / \mathrm{i} / \mathrm{eNOS}^{-/-}$mice) (Fig. 1A) (21). In this review, we first introduce our previous studies on NO that led us to develop the triply $\mathrm{n} / \mathrm{i} / \mathrm{eNOS}^{-/-}$mice and then describe in detail the generation and the initial functional analysis of those mice.

\section{Our previous studies on NO}

First, we examined the molecular mechanism for endothelial NO synthesis in pigs and humans. There are at least two different signal transduction pathways involved in the synthesis of NO by endothelial cells, Gi-protein- and Gq-protein-mediated pathways. We revealed that the Gi-protein-mediated NO production is selectively impaired in arteriosclerosis $(22,23)$, partly due to reduced expression of endothelial Gi protein $(24,25)$. This notion was subsequently confirmed in humans (26).

Secondly, we examined the effect of increasing intracellular tetrahydrobiopterin concentrations on endothelial NO synthesis in isolated canine cerebral arteries. We showed that tetrahydrobiopterin has dual effects, one is the inhibitory effect on NO production via superoxide generation induced by auto-oxidation of tetrahydrobiopterin, and the other is the stimulatory effect on NO production as a cofactor of eNOS activation $(27,28)$. These results suggest that the balance between intracellular tetrahydrobiopterin levels and the activity of antioxidant enzymes (e.g., superoxide dismutases) may be an important determinant of endothelial NO production $(27,28)$.

Thirdly, we studied the potential usefulness of eNOS gene therapy in cerebral arteries ex vivo and in vivo. We demonstrated that adventitial expression of recombinant eNOS gene restores NO production in arteries without endothelium, causing adventitia-dependent endotheliumindependent relaxations $(29-32)$. Our findings provide a novel concept that the vascular adventitia could play a role in the regulation of vascular tone after successful transfer and expression of recombinant eNOS gene
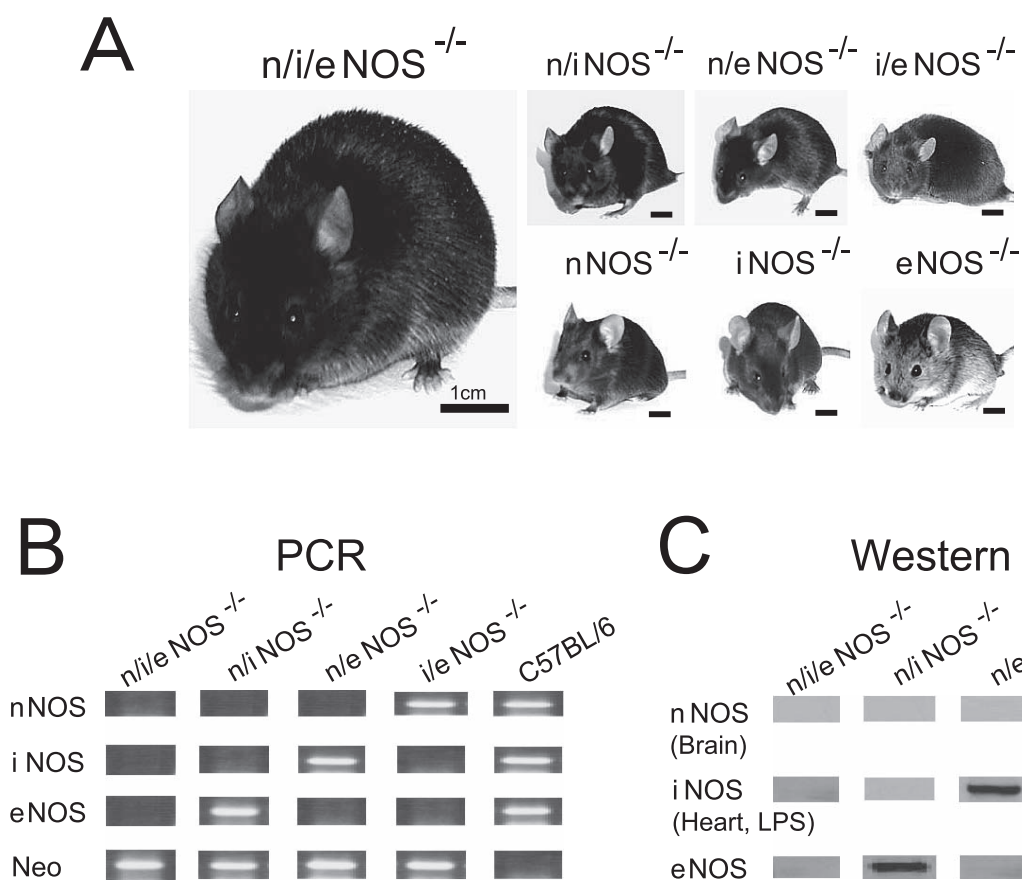

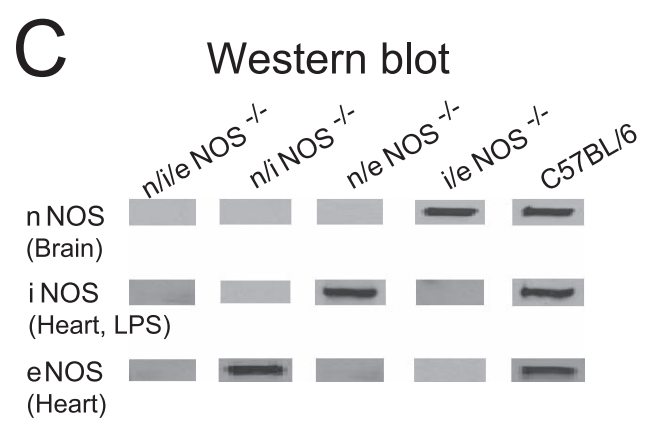

Fig. 1. Appearance (A), PCR analysis (B), and Western blot analysis (C) of wild-type and $\mathrm{NOS}^{-/}$mice. A: We first produced 3 kinds of doubly $\mathrm{NOS}^{-/}$ mice by crossbreeding singly $\mathrm{NOS}^{-/-}$mice. The doubly $\mathrm{NOS}^{-/}$ mice were then crossed, and triply $\mathrm{n} / \mathrm{i} / \mathrm{eNOS}^{-/-}$mice were finally generated. B: PCR analysis in tail genomic DNA indicated the presence of all three NOS genes in the wild-type C57BL/6 mice, but the absence of the genes in the triply $\mathrm{n} / \mathrm{i} / \mathrm{eNOS}^{-/-}$mice. C: Western blot analysis also revealed the absence of all three NOS proteins in the brain and the heart of triply $\mathrm{n} / \mathrm{i} / \mathrm{eNOS}^{-/}$mice before and after treatment with lipopolysaccharide (LPS, $20 \mathrm{mg}$ $/ \mathrm{kg}$ IP, $12 \mathrm{~h}$ ). Modified from ref. 21 . 
$(29-32)$. It is also implicated that perivascular eNOS gene delivery is a feasible new therapeutic strategy for cerebrovascular diseases.

Fourthly, we clarified the NO-independent vascular actions of L-arginine analogues (e.g., a synthetic analogue, $N^{\omega}$-nitro-L-arginine methyl ester, and an endogenous analogue, asymmetric dimethylarginine). Although long-term treatment with L-arginine analogues had long been believed without doubt to simply inhibit endothelial NO synthesis and cause arteriosclerotic vascular lesion formation, we found that the long-term vascular effects of L-arginine analogues are not mediated by simple inhibition of endothelial NO synthesis as those analogues caused similar cardiovascular lesions in both wild-type and $\mathrm{NOS}^{-/-}$mice (33, 34). Indeed, activation of the tissue renin-angiotensin system and increased oxidative stress, independent of endogenous NO inhibition, are involved in the long-term vascular effects of those analogues $(33,34)$. Our findings questioned the previous theory regarding the pro-atherogenic effects of L-arginine analogues and warranted re-evaluation of previous studies with those analogues $(33,34)$.

Fifthly, we performed lines of studies regarding the vasculoprotective roles of nNOS. Although the regulatory roles of eNOS and iNOS on the development of arteriosclerosis have been extensively investigated, little is known about the role of nNOS. We showed that in a carotid artery ligation model, $\mathrm{nNOS}^{-/-}$mice exhibited accelerated neointimal formation and constrictive vascular remodeling caused by blood flow disruption and that in a rat balloon injury model, selective inhibition of nNOS activity significantly enhanced vaso- constrictor responses to calcium-mobilizing stimuli and exacerbated neointimal formation (35). These results provide the first evidence that nNOS plays important roles in suppressing arteriosclerotic vascular lesion formation $(35,36)$. In line with our findings, a recent study reported the anti-atherogenic effect of nNOS in apolipoprotein $\mathrm{E}^{-/-}$mice (37). We further showed that nNOS could act as an "inducible" enzyme in the vascular system, in contrast to the nervous system, and that vascular nNOS expression is up-regulated in response to growth factors (e.g., angiotensin II and platelet-derived growth factor), inflammatory cytokines (e.g., interleukin-1 $\beta$ ), and HMG-CoA reductase inhibitors $(35,36,38)$.

In the series of experiments mentioned above, we were able to demonstrate that all three NOS isoforms play roles in the development of arteriosclerosis, but due to the compensated interactions among the three NOS isoforms, the role of the whole NO/NOSs system remains to be elucidated. Therefore, in order to address this point, we decided to establish genetically engineered mice lacking all NOSs.

\section{Generation of triply n/i/eNOS ${ }^{-/}$mice}

We first produced three kinds of doubly $\mathrm{NOS}^{-/-}$mice (n/iNOS ${ }^{-/-}, \mathrm{n} / \mathrm{eNOS}^{-/-}$, and $\mathrm{i} / \mathrm{eNOS}^{-/-}$mice) by crossing singly $\mathrm{NOS}^{-/-}$mice $\left(\mathrm{nNOS}^{-/-}\right.$, $\mathrm{iNOS}^{-/-}$, and $\mathrm{eNOS}^{-/-}$ mice). The doubly $\mathrm{NOS}^{-/-}$mice were then interbred over 4 to 5 generations, and triply $\mathrm{n} / \mathrm{i} / \mathrm{eNOS}^{-/-}$mice were finally developed (Fig. 1A) (21).

NO has been implicated in many biological phenomena $(1-6)$. Therefore, when we started this project, we

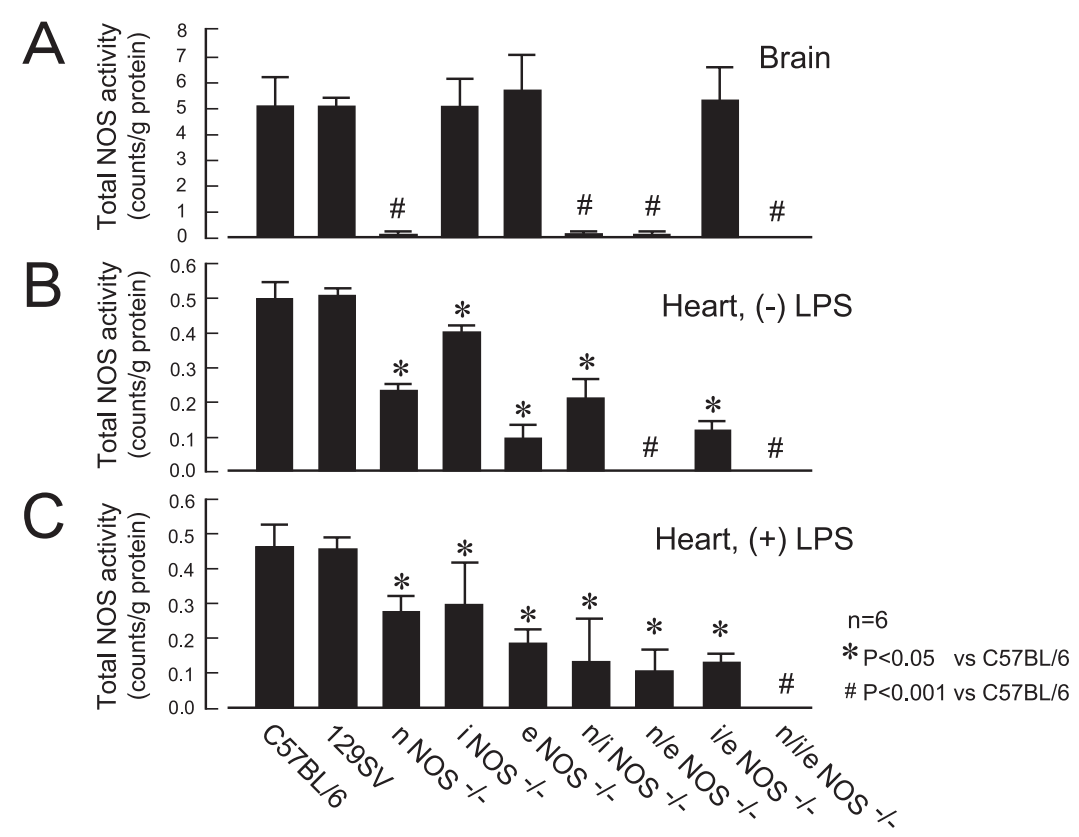

Fig. 2. Total NOS activity in the brain and the heart of wild-type and $\mathrm{NOS}^{-/-}$mice. A: In the normal brain, total NOS activity was markedly reduced in $\mathrm{nNOS}^{-/}$mice as compared with the wild-type mice, and it was completely absent in the triply $\mathrm{n} / \mathrm{i} / \mathrm{eNOS}^{-/-}$mice. B: In the normal heart, total NOS activity was significantly reduced in $\mathrm{nNOS}^{-/-}$, iNOS ${ }^{-/-}$, and $\mathrm{eNOS}^{-/-}$mice, and it was also completely deficient in the triply $\mathrm{n} / \mathrm{i} / \mathrm{eNOS}^{-/}$ mice. C: In addition, in the heart treated with lipopolysaccharide, total NOS activity was again undetected in the triply $\mathrm{n} / \mathrm{i} / \mathrm{eNOS}^{-/-}$mice. Modified from ref. 21. 

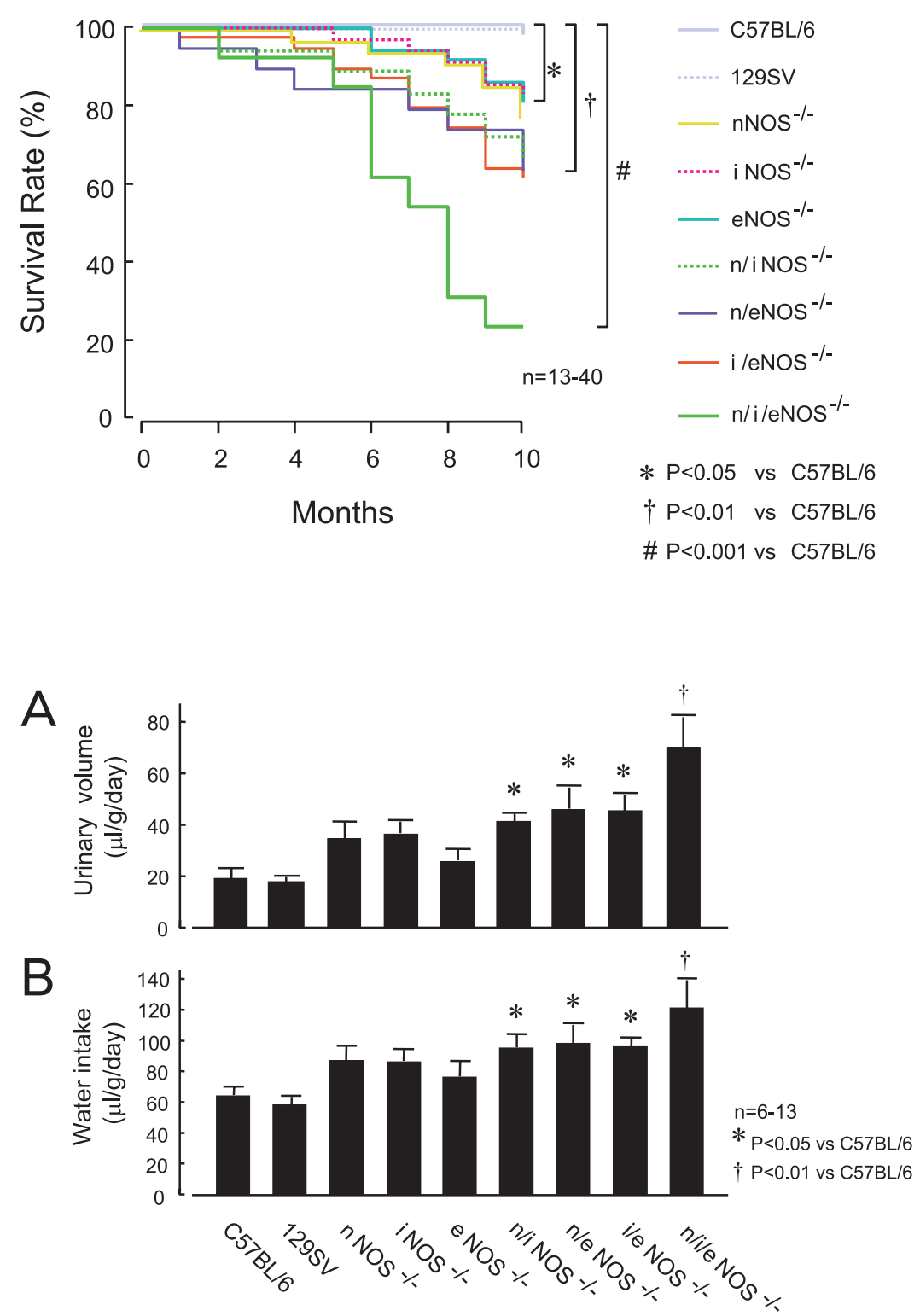

Fig. 3. Survival rate in both genders of wild-type and $\mathrm{NOS}^{-/-}$mice. During the 10 months of follow-up, all the wild-type mice lived, whereas approximately $80 \%$ of the triply $\mathrm{n} / \mathrm{i} / \mathrm{eNOS}^{-/-}$mice died. Survival rate was significantly worse in proportion to the number of disrupted NOS isoforms in the order of singly, doubly, and triply $\mathrm{NOS}^{-/-}$mice. Modified from ref. 21.

Fig. 4. Urinary volume (A) and water intake (B) in wild-type and $\mathrm{NOS}^{-/-}$mice. A: Urinary volume was significantly increased in accordance with the number of disrupted NOS genes in the order of singly, doubly, and triply $\mathrm{NOS}^{-/}$mice; and the triply $\mathrm{n} / \mathrm{i} / \mathrm{eNOS}^{-/-}$mice exhibited approximately 3 -fold increase in urinary volume as compared with the wild-type mice. B: Water intake was also significantly enhanced in the order of singly, doubly, and triply $\mathrm{NOS}^{-/-}$mice. Modified from ref. 21.

\section{A Urinary Vasopressin Excretion}

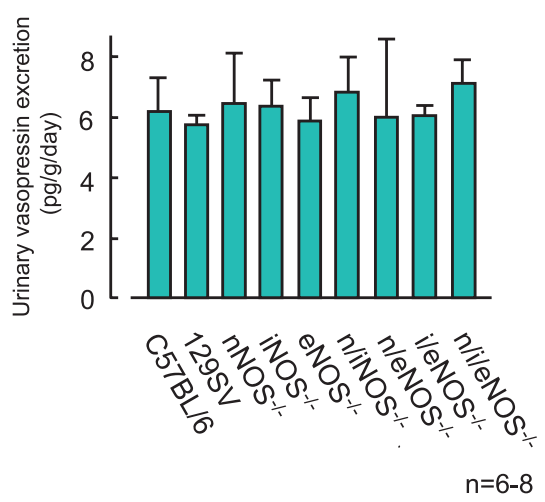

\section{B Change of Urinary Volume to}
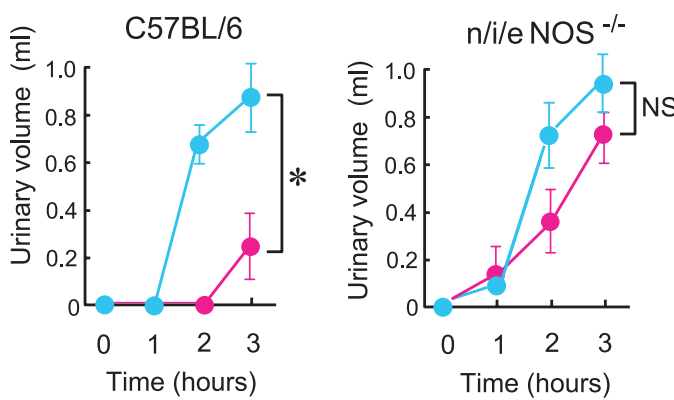

$$
\begin{array}{ll}
\mathrm{n}=6 & - \text { Without Vasopressin } \\
* \mathrm{P}<0.05 & - \text { - With Vasopressin }
\end{array}
$$

Fig. 5. Central vasopressin release (A) and renal sensitivity to vasopressin (B) in wild-type and $\mathrm{NOS}^{-/}$ mice. A: Central vasopressin secretion, as assessed by urinary vasopressin excretion, was normal in the triply $\mathrm{n} / \mathrm{i} / \mathrm{eNOS}^{-/-}$mice as compared with the wild-type mice. B: Administration of synthetic vasopressin (0.002 unit, IP) significantly reduced urinary volume in the wildtype C57BL/6 mice, whereas this anti-diuretic effect was markedly impaired in the triply $\mathrm{n} / \mathrm{i} / \mathrm{eNOS}^{-/}$ mice. From these results, we identified that the triply $\mathrm{n} / \mathrm{i} / \mathrm{eNOS}^{-/-}$mice suffer from nephrogenic diabetes insipidus. Modified from ref. 21. 
expected that triply $\mathrm{n} / \mathrm{i} / \mathrm{eNOS}^{-/-}$mice could be embryolethal, which, however, was not the case. The triply $\mathrm{n} / \mathrm{i} / \mathrm{eNOS}^{-/-}$mice were fertile and indistinguishable from wild-type animals in appearance (Fig. 1A). They developed normally and were able to mate with normal increase in body weight. The triply $\mathrm{n} / \mathrm{i} / \mathrm{eNOS}^{-/-}$mice were devoid of all NOSs protein expression and total NOS enzymatic activity (Fig. 1: B and C). Because alternatively spliced forms of nNOS and iNOS have been identified (39), we paid a special attention to the possible remaining NOS expression and function. In the triply $\mathrm{n} / \mathrm{i} / \mathrm{eNOS}^{-/-}$mice, however, we did not detect any expression (Fig. 1: B and C) or enzyme activity of nNOS or iNOS in the brain, heart (Fig. 2), or kidney (data not shown) either before or after administration of lipopolysaccharide (Fig. 2). Thus, the NOS system is completely disrupted in our triply $\mathrm{n} / \mathrm{i} / \mathrm{eNOS}^{-/-}$mice.

We next studied whether systemic NO production was also completely defective in the triply $\mathrm{n} / \mathrm{i} / \mathrm{eNOS}^{-/}$ mice. As expected, both plasma NOx concentrations and urinary NOx excretion, markers of systemic NO production, were extremely low (approx. 3\% of normal value) in the triply $\mathrm{n} / \mathrm{i} / \mathrm{eNOS}^{-/-}$mice, indicating that most of endogenous NO is derived from NOSs. The remaining $\mathrm{NO}$ production in the triply $\mathrm{NOS}^{-/-}$mice could be due to a NOS-independent mechanism (40). Indeed, bacteria, especially enterobacterium, synthesize NOx via active nitric acid metabolism, and myoglobin in turn generates NO from NOx (41). In addition, catalase could also produce NO from hydroxylamine or sodium azide (42).

\section{Survival and fertility in triply $\mathrm{n} / \mathrm{i} / \mathrm{eNOS}^{-/-}$mice}

We then examined the survival and the fertility of the triply $\mathrm{NOS}^{-/}$mice. Experiments were performed in both genders of the following 9 strains: wild-type C57BL and $129 \mathrm{SV}$ mice; singly $\mathrm{nNOS}^{-/-}$, $\mathrm{NOS}^{-/}$, and $\mathrm{eNOS}^{-/-}$; doubly n/iNOS ${ }^{-/-}, \mathrm{n} / \mathrm{eNOS}^{-/-}$, and i/eNOS ${ }^{-/}$; and triply $\mathrm{n} / \mathrm{i} / \mathrm{eNOS}^{-/-}$mice. During the 10 -months follow-up, all wild-type mice lived, whereas only 3 of the 13 triply $\mathrm{NOS}^{-/}$mice (23\%) survived (Fig. 3) (21). Survival rate was significantly worse in accordance with the number of disrupted NOS genes (Fig. 3). The number of offspring produced from breeding pairs was also significantly smaller in the same manner (21). These results indicate an essential role of the NOS system in survival and fertility. The findings also suggest that each NOS isoform individually plays an important role in survival and fertility. We have recently revealed that the survival rate was significantly better in female than in male triply $\mathrm{NOS}^{-/-}$mice (unpublished observation). It is thus conceivable that female hormone plays an important role in the survival of the triply $\mathrm{NOS}^{-/-}$mice.
We next investigated the cause of death in the triply $\mathrm{n} / \mathrm{i} / \mathrm{eNOS}^{-/-}$mice. Our unpublished observation revealed that more than half of the male triply $\mathrm{n} / \mathrm{i} / \mathrm{eNOS}^{-/-}$mice died due to myocardial infarction associated with severe arteriosclerotic coronary lesions. In all the dead triply $\mathrm{n} / \mathrm{i} / \mathrm{eNOS}^{-/-}$mice, adventitial mast cell infiltration of the coronary arteries was noted (21). Since previous studies have revealed that histamine released from mast cells causes coronary artery spasm in the arteriosclerotic coronary artery, myocardial ischemia induced by coronary artery spasm may be involved, at least in part, in the cause of death in the triply $\mathrm{n} / \mathrm{i} / \mathrm{eNOS}^{-/-}$mice (21).

The mouse with homozygous null mutations in the genes for both the high-density lipoprotein (HDL) receptor SR-BI and apolipoprotein E (apoE) is known as a murine model of spontaneous myocardial infarction (43). However, the longevity of this SR-BI/apoE double knockout mouse is extremely short, and even when fed a standard chow diet, all mice die before 2 months of age. To the best of our knowledge, our triply $\mathrm{n} / \mathrm{i} / \mathrm{eNOS}^{-/-}$mouse is the first murine model of spontaneous myocardial infarction, and thus can be a useful model to study the pathogenesis of the disorder.

\section{Nephrogenic diabetes insipidus in triply n/i/eNOS mice}

Since the triply $\mathrm{n} / \mathrm{i} / \mathrm{eNOS}^{-/-}$mice were very precious because of poor survival and fertility, we first performed non-invasive analysis without killing the animals. Because our initial observation suggested the presence of polyuria in the triply $\mathrm{n} / \mathrm{i} / \mathrm{eNOS}^{-/-}$mice, we examined body water balance. The triply $\mathrm{n} / \mathrm{i} / \mathrm{eNOS}^{-/-}$mice showed prominent polyuria, polydipsia, and dehydration as compared with wild-type mice (Fig. 4) (21). Regarding the pathogenesis of the polyuria, osmotic diuresis, or water diuresis should be differentiated. In the triply $\mathrm{n} / \mathrm{i} / \mathrm{eNOS}^{-/-}$mice, the urine was hypotonic, low ionic, and without glucose, excluding osmotic diuresis due to natriuresis and diabetes mellitus (21). Water diuresis is caused by either central or nephrogenic diabetes insipidus or psychogenic polydipsia. Psychogenic polydipsia can be excluded because the triply $\mathrm{n} / \mathrm{i} / \mathrm{eNOS}^{-/}$ mice had dehydration. Next, to distinguish between central and nephrogenic diabetes insipidus, we examined the release of and the renal sensitivity to vasopressin. In the triply $\mathrm{n} / \mathrm{i} / \mathrm{eNOS}^{-/-}$mice, renal responsiveness to exogenous vasopressin was markedly impaired, while vasopressin release was unaltered, identifying the nephrogenic origin of diabetes insipidus in those mice (Fig. 5) (21). Nephrogenic diabetes insipidus is classified into two major categories: hereditary (or congenital) and acquired. Acquired nephrogenic diabetes insipidus 
is induced by electrolyte abnormalities (e.g., hypercalcemia or hypokalemia) or renal insufficiency of any cause. In the triply $\mathrm{NOS}^{-/-}$mice, plasma $\mathrm{Ca}^{2+}$ and $\mathrm{K}^{+}$ concentrations were normal, while renal tubular apoptosis and regeneration, glomerulosclerosis, and glomerular thrombi were noted (21). These results suggest that the deletion of the whole NOS system is the primary cause of renal structural changes that result in nephrogenic diabetes insipidus.

The extent of tubular ischemic injury by glomerular thrombi is usually more severe in proximal tubules than in distal or collecting tubules. However, tubular lesions in the triply $\mathrm{n} / \mathrm{i} / \mathrm{eNOS}^{-/}$mice were detected predominantly in the distal and collecting tubules rather than in the proximal tubules (21). It is thus conceivable that the tubular lesions are not caused by glomerular thrombiinduced ischemia.

Under physiological conditions, vasopressin stimulates adenylate cyclase, increases cAMP production, and activates cAMP-dependent protein kinase via the $\mathrm{V}_{2}$ receptor in renal collecting duct principal cells. Phosphorylation of aquaporin-2 by the kinase in turn leads to translocation of aquaporin-2 from cytoplasmic vesicles to the apical plasma membrane, thereby increasing water permeability and reabsorption. Nephrogenic diabetes insipidus is characterized by an inability to concentrate urine despite normal or elevated plasma concentrations of vasopressin. In inherited nephrogenic diabetes insipidus, renal responsiveness to vasopressin is impaired by abnormalities of the vasopressin $\mathrm{V}_{2}$ receptor or by those of the vasopressin-regulated water channel, aquaporin-2. To further clarify the mechanism involved, we examined cAMP accumulation and localization of aquaporin-2 in the collecting ducts of 1-week old triply $\mathrm{n} / \mathrm{i} / \mathrm{eNOS}^{--}$mice before the development of structural abnormalities. Vasopressin-stimulated cAMP accumulation, but not basal cAMP accumulation, was significantly reduced in the collecting ducts of the triply $\mathrm{n} / \mathrm{i} / \mathrm{eNOS}^{-/}$mice, as compared with wild-type mice (21). Furthermore, expression of aquaporin-2 in collecting duct plasma membrane was more significantly decreased in the triply $\mathrm{NOS}^{-/-}$than in wild-type mice (21). These results suggest that reduced cAMP production and decreased aquaporin-2 expression are also involved in the pathogenesis of nephrogenic diabetes insipidus in the triply $\mathrm{n} / \mathrm{i} / \mathrm{eNOS}^{-/-}$mice. Consistent with our notion, previous studies revealed that NO stimulates cAMP production via cGMP-dependent activation of adenylate cyclase in isolated rat kidney and that NO promotes the membrane insertion of aquaporin-2 in collecting duct $(44,45)$. Importantly, the occurrence of functional abnormalities preceded that of structural abnormalities. Thus, the triply $\mathrm{n} / \mathrm{i} / \mathrm{eNOS}^{-/-}$mice appear to possess the feature of inherited, rather than acquired, nephrogenic diabetes insipidus.

\section{Cardiovascular phenotypes in triply $\mathrm{n} / \mathrm{i} / \mathrm{eNOS}^{-/-}$mice}

We have recently tested our hypothesis that vascular lesion formation is spontaneously developed in the triply $\mathrm{n} / \mathrm{i} / \mathrm{eNOS}^{-/-}$mice (46). Experiments were performed in male wild-type; singly $\mathrm{nNOS}^{-/-}$, $\mathrm{iNOS}^{-/-}$, and $\mathrm{eNOS}^{-/-}$; and triply $\mathrm{n} / \mathrm{i} / \mathrm{eNOS}^{-/-}$mice at 2 and 5 months of age maintained on regular diet. At 2 months of age, no significant vascular lesions were detected in any strains studied. However, at 5 months of age, significant wall thickening and perivascular fibrosis were noted only in the triply $\mathrm{NOS}^{-/-}$mice, but not in other strains, in both large epicardial coronary arteries and coronary microvessels (46). Furthermore, similar vascular lesions were also noted in cerebral and renal arteries and aortas, only in the triply $\mathrm{NOS}^{-/-}$mice. Notably, vascular angiotensin-converting enzyme immunoreactivities and cardiac superoxide production (by lucigenin chemiluminescence) were markedly enhanced only in the triply $\mathrm{NOS}^{-/-}$mice. These results indicate that the complete deletion of the whole NOS system accelerates a spontaneous development of systemic arteriosclerosis, associated with upregulation of angiotensin-converting enzyme and increased oxidative stress (46).

We further examined whether or not cardiovascular risk factors are present in the triply $\mathrm{NOS}^{-/-}$mice (47). Triply $\mathrm{n} / \mathrm{i} / \mathrm{eNOS}^{-/-}$mice showed hypertension and hypertriglyceridemia as compared with wild-type mice. Those mice also exhibited impaired glucose tolerance and severe insulin resistance compared with wild-type mice. Furthermore, visceral obesity associated with adipocyte hypertrophy was noted in the triply $\mathrm{n} / \mathrm{i} / \mathrm{eNOS}^{-/-}$mice; these are all characteristics consistent with human metabolic syndrome. Importantly, supplementation of NO by long-term dermal application of isosorbide dinitrate normalized those metabolic phenotypes in the triply $\mathrm{n} / \mathrm{i} / \mathrm{eNOS}^{-/-}$mice (the authors' unpublished observations). These results suggest an important role of defective NO production in the pathogenesis of metabolic syndrome (47).

\section{Concluding remarks}

We have successfully developed genetically engineered animals deficient in all three NOSs. In the functional analysis, we were able to demonstrate that the triply $\mathrm{n} / \mathrm{i} / \mathrm{eNOS}^{-/-}$mice manifested phenotypes of aging, arteriosclerosis, coronary artery spasm, metabolic syndrome, and nephrogenic diabetes insipidus (Fig. 6). These findings provide the first evidence that genetic 


\section{Cardiovascular Phenotypes in Mice Lacking All NOSs}

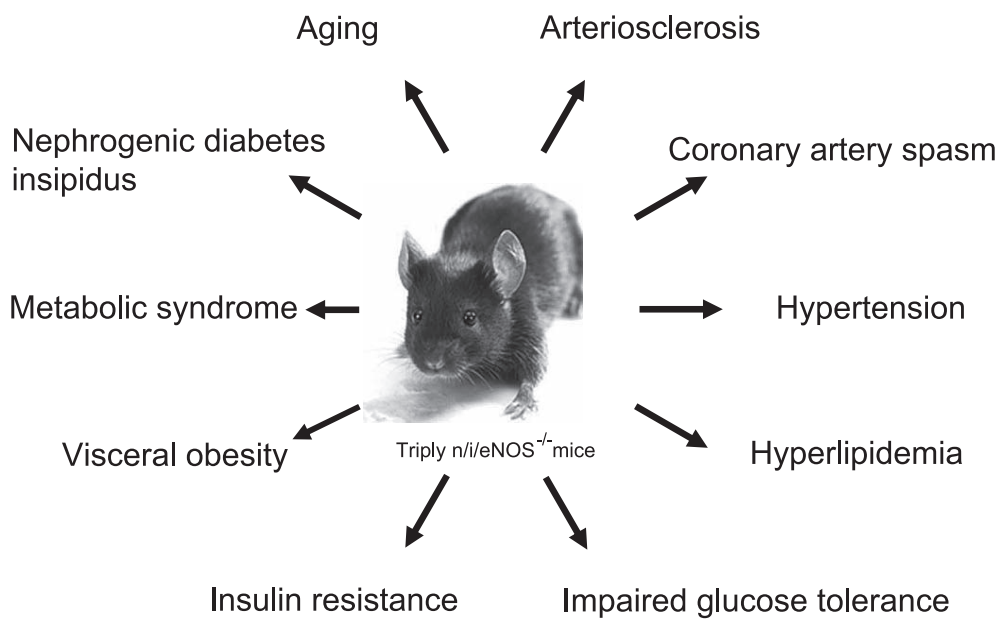

Fig. 6. Schematic diagram showing the cardiovascular phenotypes in mice lacking all NOSs. The triply $\mathrm{n} / \mathrm{i} / \mathrm{eNOS}^{-/-}$mice manifest a variety of cardiovascular phenotypes, including aging, arteriosclerosis, coronary artery spasm, metabolic syndrome, and nephrogenic diabetes insipidus. These findings demonstrate a central role of NO derived from the whole NOS system in the pathogenesis of the cardiovascular diseases. Our triply mutant mouse is a new animal model of the disorders. disruption of the whole NOS system causes a variety of cardiovascular diseases in mice in vivo, demonstrating the central role of defective NO production in the pathogenesis of those disorders.

The roles of NO have so far been extensively investigated in pharmacological experiments or in experiments using mice deficient in each NOS isoform. However, in pharmacological experiments, there are always problems regarding the selectivity and specificity of drugs, while in the mice deficient in each NOS isoform, compensatory mechanisms by other NOSs are apparently involved. Our triply $\mathrm{n} / \mathrm{i} / \mathrm{eNOS}^{-/-}$mouse is a useful experimental tool to solve those problems and to investigate the roles of the whole NOS system.

\section{Acknowledgments}

The authors wish to thank Professors Y. Sasaguri and Y. Ueta and all our coworkers at the University of Occupational and Environmental Health, especially Drs. H. Tasaki, A. Tanimoto, Ke-Yong Wang, O. Suda, S. Nakata, and K Sabanai for their collaboration in the present studies. The authors' works presented in this article were supported in part by Grants-in-Aid for Scientific Research 17390071 and 14570096 and Grants-in-Aid for Exploratory Research 16650097 and 16659209 from the Ministry of Education, Culture, Sports, Science and Technology, Japan and by grants from the Yamanouchi Pharmaceutical Co., the Japan Foundation of Cardiovascular Research, the Mochida Memorial Foundation for Medical and Pharmaceutical Research, the Yamanouchi Foundation for Research on Metabolic Disorders, the Kimura Memorial Cardiovascular Foundation, the Ichiro Kanehara Foundation, the Takeda Medical Research Foundation, and the
University of Occupational and Environmental Health, Kitakyushu, Japan.

\section{References}

1 Bredt DS, Snyder SH. Nitric oxide: a physiological messenger molecule. Annu Rev Biochem. 1994;63:175-195.

2 Furchgott RF. The role of endothelium in the responses of vascular smooth muscle to drugs. Annu Rev Pharmacol Toxicol. 1984;24:175-197.

3 Ignarro LJ. Biosynthesis and metabolism of endotheliumderived nitric oxide. Annu Rev Pharmacol Toxicol. 1990;30: 535-560.

4 Moncada S, Palmer RMJ, Higgs EA. Nitric oxide: physiology, pathophysiology, and pharmacology. Pharmacol Rev. 1991;43: 109-142.

5 Murad F. What are the molecular mechanisms for the antiproliferative effects of nitric oxide and cGMP in vascular smooth muscle? Circulation. 1997;95:1101-1103.

6 Shimokawa H. Primary endothelial dysfunction: atherosclerosis. J Mol Cell Cardiol. 1999;31:23-37.

7 Godecke A, Decking UK, Ding Z, Hirchenhain J, Bidmon HJ, Godecke $\mathrm{S}$, et al. Coronary hemodynamics in endothelial NO synthase knockout mice. Circ Res. 1998;82:186-194.

8 Gyurko R, Leupen S, Huang PL. Deletion of exon 6 of the neuronal nitric oxide synthase gene in mice results in hypogonadism and infertility. Endocrinology. 2002;143:2767-2774.

9 Huang PL, Dawson TM, Bredt DS, Snyder SH, Fishman MC. Targeted disruption of the neuronal nitric oxide synthase gene. Cell. 1993;75:1273-1286.

10 Huang PL, Huang Z, Mashimo H, Bloch KD, Moskowitz MA, Bevan JA, et al. Hypertension in mice lacking the gene for endothelial nitric oxide synthase. Nature. 1995;377:239-242.

11 Laubach VE, Shesely EG, Smithies O, Sherman PA. Mice lacking inducible nitric oxide synthase are not resistant to lipopolysaccharide-induced death. Proc Natl Acad Sci U S A. 1995;92:10688-10692.

12 MacMicking JD, Nathan C, Hom G, Chartrain N, Fletcher DS, Trumbauer M, et al. Altered responses to bacterial infection and endotoxic shock in mice lacking inducible nitric oxide synthase. Cell. 1995;81:641-650. 
13 Nelson RJ, Demas GE, Huang PL, Fishman MC, Dawson VL, Dawson TM, et al. Behavioural abnormalities in male mice lacking neuronal nitric oxide synthase. Nature. 1995;378:383-386.

14 Shesely EG, Maeda N, Kim HS, Desai KM, Krege JH, Laubach VE, et al. Elevated blood pressures in mice lacking endothelial nitric oxide synthase. Proc Natl Acad Sci U S A. 1996;93: 13176-13181.

15 Son H, Hawkins RD, Martin K, Kiebler M, Huang PL, Fishman $\mathrm{MC}$, et al. Long-term potentiation is reduced in mice that are doubly mutant in endothelial and neuronal nitric oxide synthase. Cell. 1996;87:1015-1023.

16 Tranguch S, Huet-Hudson Y. Decreased viability of nitric oxide synthase double knockout mice. Mol Reprod Dev. 2003;65:175179.

17 Wei XQ, Charles IG, Smith A, Ure J, Feng GJ, Huang FP, et al. Altered immune responses in mice lacking inducible nitric oxide synthase. Nature. 1995;375:408-411.

18 Huang Z, Huang PL, Panahian N, Dalkara T, Fishman MC, Moskowitz MA. Effects of cerebral ischemia in mice deficient in neuronal nitric oxide synthase. Science. 1994;265:1883-1885.

19 Huang Z, Huang PL, Ma J, Meng W, Ayata C, Fishman MC, et al. Enlarged infarcts in endothelial nitric oxide synthase knockout mice are attenuated by nitro-L-arginine. J Cereb Blood Flow Metab. 1996;16:981-987.

20 Yogo K, Shimokawa H, Funakoshi H, Kandabashi T, Miyata K, Okamoto S, et al. Different vasculoprotective roles of $\mathrm{NO}$ synthase isoforms in vascular lesion formation in mice. Arterioscler Thromb Vasc Biol. 2000;20:E96-E100.

21 Morishita T, Tsutsui M, Shimokawa H, Sabanai K, Tasaki H, Suda O, et al. Nephrogenic diabetes insipidus in mice lacking all nitric oxide synthase isoforms. Proc Natl Acad Sci US A. 2005;102:10616-10621.

22 Shimokawa H, Flavahan NA, Vanhoutte PM. Natural course of the impairment of endothelium-dependent relaxations after balloon endothelium removal in porcine coronary arteries. Possible dysfunction of a pertussis toxin-sensitive $G$ protein. Circ Res. 1989;65:740-753.

23 Shimokawa H, Flavahan NA, Vanhoutte PM. Loss of endothelial pertussis toxin-sensitive $G$ protein function in atherosclerotic porcine coronary arteries. Circulation. 1991;83:652-660.

24 Shimokawa H, Tsutsui M, Mizuki T, Hase K, Kuwaoka I, Nogami N, et al. Endothelial Gi protein expression is markedly low in human coronary microvessels. J Cardiovasc Pharmacol. 1996;27:297-302.

25 Tsutsui M, Shimokawa H, Tanaka S, Kuwaoka I, Hase K, Nogami N, et al. Endothelial Gi protein in human coronary arteries. Eur Heart J. 1994;15:1261-1266.

26 Huraux C, Makita T, Kurz S, Yamaguchi K, Szlam F, Tarpey $\mathrm{MM}$, et al. Superoxide production, risk factors, and endothelium-dependent relaxations in human internal mammary arteries. Circulation. 1999;99:53-59.

27 Kinoshita H, Tsutsui M, Milstien S, Katusic ZS. Tetrahydrobiopterin, nitric oxide and regulation of cerebral arterial tone. Prog Neurobiol. 1997;52:295-302.

28 Tsutsui M, Milstien S, Katusic ZS. Effect of tetrahydrobiopterin on endothelial function in canine middle cerebral arteries. Circ Res. 1996;79:336-342.

29 Tsutsui M, Chen AF, O'Brien T, Crotty TB, Katusic ZS. Adventitial expression of recombinant eNOS gene restores NO production in arteries without endothelium. Arterioscler Thromb Vasc Biol. 1998;18:1231-1241.

30 Tsutsui M, Onoue H, Iida Y, Smith L, O’Brien T, Katusic ZS. Adventitia-dependent relaxations of canine basilar arteries transduced with recombinant eNOS gene. Am J Physiol 1999;276:H1846-H1852.

31 Tsutsui M, Onoue H, Iida Y, Smith L, O'Brien T, Katusic ZS. Effects of recombinant eNOS gene expression on reactivity of small cerebral arteries. Am J Physiol. 2000;278:H420-H427.

32 Tsutsui M, Onoue H, Iida Y, Smith L, O'Brien T, Katusic ZS. $\mathrm{B} 1$ and $\mathrm{B} 2$ bradykinin receptors on adventitial fibroblasts of cerebral arteries are coupled to recombinant eNOS. Am J Physiol. 2000;278:H367-H372.

33 Suda O, Tsutsui M, Morishita T, Tanimoto A, Horiuchi M, Tasaki H, et al. Long-term treatment with N(omega)-nitro-Larginine methyl ester causes arteriosclerotic coronary lesions in endothelial nitric oxide synthase-deficient mice. Circulation. 2002;106:1729-1735.

34 Suda O, Tsutsui M, Morishita T, Tasaki H, Ueno S, Nakata S, et al. Asymmetric dimethylarginine produces vascular lesions in endothelial nitric oxide synthase-deficient mice. Arterioscler Thromb Vasc Biol. 2004;24:1682-1688.

35 Morishita T, Tsutsui M, Shimokawa H, Horiuchi M, Tanimoto A, Suda O, et al. Vasculoprotective roles of neuronal nitric oxide synthase. FASEB J. 2002;16:1994-1996.

36 Tsutsui M. Neuronal nitric oxide synthase as a novel antiatherogenic factor. J Atheroscler Thromb. 2004;11:41-48.

37 Kuhlencordt PJ, Hotten S, Schodel J, Rutzel S, Hu K, Widder J, et al. Atheroprotective effects of neuronal nitric oxide synthase in apolipoprotein e knockout mice. Arterioscler Thromb Vasc Biol. 2006;26:1539-1544.

38 Nakata S, Tsutsui M, Shimokawa H, Tamura M, Tasaki H, Morishita T, et al. Vascular neuronal NO synthase is selectively upregulated by platelet-derived growth factor: involvement of the MEK/ERK pathway. Arterioscler Thromb Vasc Biol. 2005;25:2502-2508.

39 Geller DA, Billiar TR. Molecular biology of nitric oxide synthases. Cancer Metastasis Rev. 1998;17:7-23.

40 Lundberg JO, Weitzberg E. NO generation from nitrite and its role in vascular control. Arterioscler Thromb Vasc Biol. 2005;25:915-922.

41 Koizumi C, Brown WD. Formation of nitric oxide myoglobin by nicotinamide adenine dinucleotides and flavins. J Food Sci. 1971;36:1105-1109.

42 Nichol CA, Smith GK, Duch DS. Biosynthesis and metabolism of tetrahydrobiopterin and molybdopterin. Ann Rev Biochem. 1985;54:729-764.

43 Braun A, Trigatti BL, Post MJ, Sato K, Simons M, Edelberg JM, et al. Loss of SR-BI expression leads to the early onset of occlusive atherosclerotic coronary artery disease, spontaneous myocardial infarctions, severe cardiac dysfunction, and premature death in apolipoprotein E-deficient mice. Circ Res. 2002;90:270-276.

44 Heuze-Joubert I, Mennecier P, Simonet S, Laubie M, Verbeuren TJ. Effect of vasodilators, including nitric oxide, on the release of cGMP and cAMP in the isolated perfused rat kidney. Eur $\mathrm{J}$ Pharmacol. 1992;220:161-171.

45 Pelligrino DA, Wang Q. Cyclic nucleotide crosstalk and the regulation of cerebral vasodilation. Prog Neurobiol. 1998;56:1-18.

46 Nagasaki M, Tsutsui M, Shimokawa H, Morishita T, Nakata S, Sabanai K, et al. Spontaneous development of systemic arteriosclerosis in mice lacking all nitric oxide synthase isoforms. Circulation. 2005;112:II-166.

47 Nakata S, Tsutsui M, Sabanai K, Morishita T, Nagasaki M, Yanagihara N. A new animal model of multiple risk factor syndrome: mice lacking all nitric oxide synthase isoforms. Circulation. 2005;112:II-56. 